\title{
EXTENSIVE PAST DISTRIBUTIONS FOR MAJOR GONDWANIC FLORAL ELEMENTS: MACROFOSSIL EVIDENCE
}

\author{
by Robert S. Hill and Raymønd J. Carpenter \\ (with one text-figure and an appendix)
}

\begin{abstract}
The past geog raphical positions and climates of the high latitude Southern Hemisphere land masses (New Zealand and the southem parts of South America and Australia) are crucial to an understanding of plant evolution and migration in the region. A review of the macrofossil record reveals many examples of taxa which are present as fossils on one or two of these land masses but now occur elsewhere in the Southern Hemisphere. The main examples include Austrocedrus, Libocedrus (Cupressaceae), Araucaria sectionColumbea (Araucariaceae) and Nothofagus subgenera Nothofagus and Fuscaspora in Australia, Eucalyptus (Myrtaceae) and non-Gymnostoma Casuarinaceae in New Zealand and probably South America, Araucaria section Intermedia in New Zealand and Akania (Akaniaceae) and Dacrycarpus (Podocarpaceae) in South America. The local extinction of these taxa is probably due to a variety of factors, including climatic change, microsite changes due to the northward movement of land masses, and changes in the frequency of catastrophic disturbance.
\end{abstract}

https://doi.org/10.26749/rstpp.124.2.239

Key Words: macrofossils, Tertiary, Southern Hemisphere, Gondwana, biogeography, fossils, Australia, New Zealand, South America.

\section{INTRODUCTION}

The floristic similarity among the high latitude Southern Hemisphere land masses first noted by Hooker (1860) is well entrenched in the botanical literature and not disputed. For example, woody plant genera common in Tasmania, such as Nothofagus, Lomatia, Eucryphia, Dracophyllum, Podocarpus and Phyllocladus all have species in either or both New Zealand and South America. Others, such as Weinmannia, Griselinia and Fuchsia occur in South America and New Zealand but not Australia. However, the events leading to this present floristic similarity are not well understood, and debate over the origins of the constituent taxa continues.

The Southern Hemisphere land masses were once connected into a single continent, Gondwana (fig. 1), and for a long time the climate was suitable for plants and animals to migrate widely across dry land. However, in the Mesozoic Gondwana began to fragment, and the resultant land masses have changed their positions markedly, bringing about major climatic changes. These features have led to major evolutionary changes among the flora and fauna of each land mass, including major extinction events (most notably on Antarctica). These changes cloud any biogeographic analysis of the Southern Hemisphere floras based solely on living plants.

The fossil record provides evidence for past plant distributions and interrelationships which should assist in reconstructing the past history of the high latitude flora. The pollen and spore record is well understood, but offers only a partial explanation since it is widely acknowledged that it suffers from two major problems for this type of research. Firstly, pollen grains of many species can travel very large distances prior to deposition, and therefore their presence is of limited use in assessing past geographicdistributions. Secondly, it is rare for the taxonomic affinities of fossil pollen or spores to be well enough understood to allow a very detailed comparison among different land masses. Fossil palynomorphs can sometimes be allied to an extant genus, but rarely to species or species groups. This limits their utility for tracing the history of living plants.

The macrofossil record is less prone to these problems. Macrofossils (leaves, wood or reproductive structures) are rarely transported more than a few metres from their source to the point of deposition and therefore represent the local flora (e.g. Spicer 1989). There are usually more taxonomic characters available for macrofossils than for palynomorphs, and consequently their taxonomic affinities can usually be detennined to a higher resolution. The major problems are:

(1) macrofossils are relatively rare compared with palynomorphs;

(2) most macrofossils are leaves and, despite the relatively large number of taxonomic characters available, the scarcity of information on the morphology of leaves of most living species means that the affinities of many fossils remain unknown; and

(3) macrofossils are particularly biased towards plants which grew near water sources (and hence sedimentary environments), and therefore a large part of the flora is 


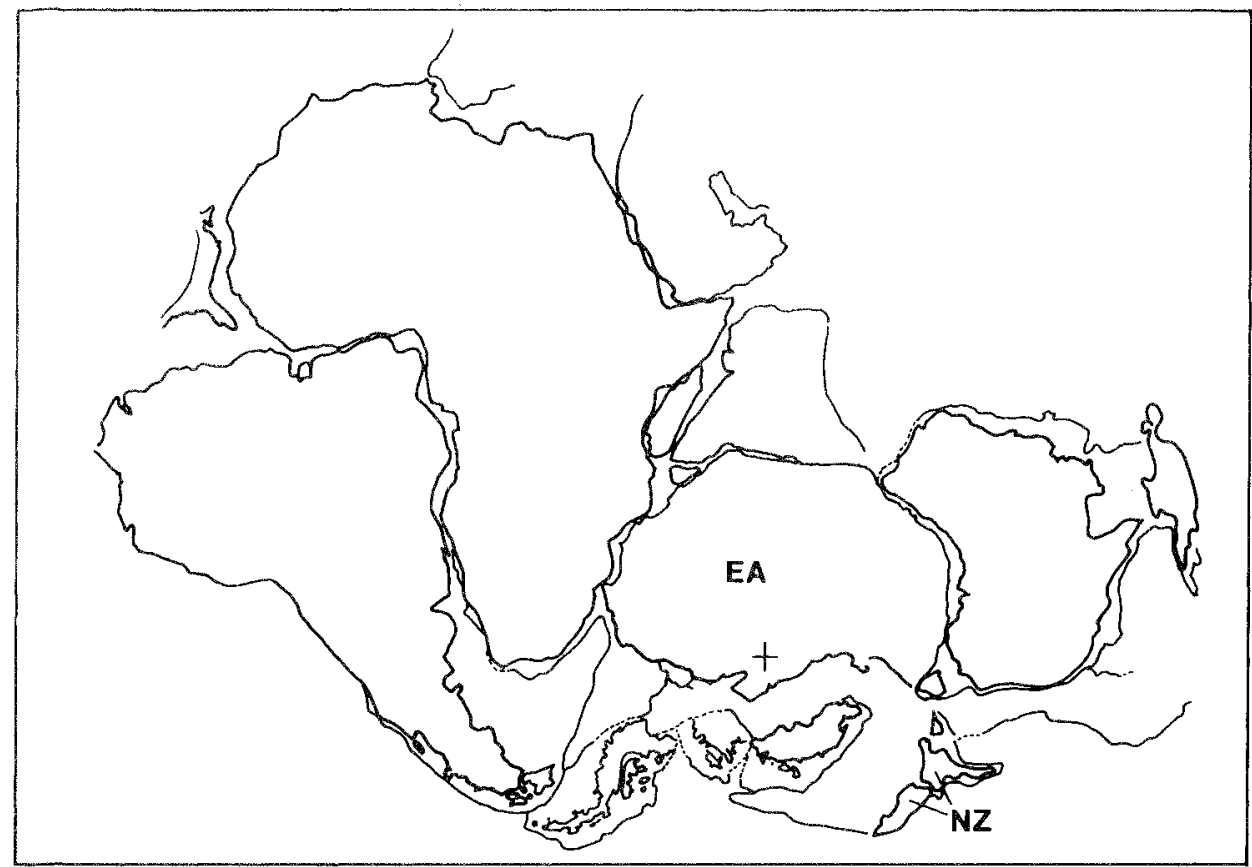

FIG. 1-Distribution of continental plates in pre-dispersal Gondwana.

under-represented or completely absent from the macrofossil record.

The aim of this study is to review the history of species which occur as macrofossils in New Zealand, southern Australia and/or southern South America. We will concentrate on those species which occur today as fossils in a land mass where they are no longer present, but which have closely related species on one or both of the other land masses under consideration. In many cases the living range of the extant species is more equatorial than the fossils, and so for living relatives the latitudinal range was extended to the equator. Consequently, according to their geological histories, New Guinea was considered to be part of Australia and New Caledonia part of New Zealand. Such fossil species are of particular importance in reconstructing past distributions and migration patterns of Gondwanic plants.

\section{PAST CONTINENTAL POSITIONS AND CLIMATE}

In order to discuss past plant distributions adequately it is important to consider the past positions of the relevant land masses and the prevailing climate during the appropriate time. From a survey of the literature the following conclusions were drawn:

(1) Tasmania and New Zealand were in close proximity in Gondwana (Lawver \& Scotese 1987), and a dispersal route between these land masses and South America occurred via West Antarctica.

(2) New Zealand was an isolated land mass by 80 $60 \mathrm{Ma}$ (Crook 1981), and the Tasman Sea had reached its present proportions by 55-57 Ma (Kamp 1986, Stock \& Molnar 1987).

(3) Australia began to separate from Antarctica about $55 \mathrm{Ma}$ (Crook \& Belbin 1978) and by $50 \mathrm{Ma}$ the southern ocean was a pronounced seaway, but oceanic depths were not achieved until $30 \mathrm{Ma}$ (Coleman 1980). (4) The Drake Passage was open by 29.3 Ma (Barker \& Burrell 1977), but oceanic depths were not achieved until 23.5 Ma (Crook 1981). The climate between about $30 \mathrm{Ma}$ and about $23 \mathrm{Ma}$ changed dramatically at high latitudes, with a general cooling trend, a decrease in rainfall, which became more seasonal, and a decline in humidity (Kemp 1978, 1981).

(5) Aridity increased from about $13 \mathrm{Ma}$ (Truswell \& Harris 1982, Stein \& Robert 1986).

It is clear that land-based dispersal between South America and Australia had ceased by $50 \mathrm{Ma}$, and New Zealand was isolated even earlier, although some long 
distance dispersal may have occurred following separation (Martin 1982). During the last 50 million years plants in the three land masses have been subjected to major climatic changes which have led to evolution, extinction and changes in distribution.

\section{THE TERTIARY MACROFOSSIL RECORD}

While Cretaceous fossil records should be important for this discussion, a literature search revealed no macrofossil records of relevance from this time period. Therefore the following discussion is based on Tertiary plant fossils. There has been extensive research on plant macrofossils from Tertiary sediments in South America, Australia and New Zealand in the last century. However, much of this record in unreliable, particularly that which was carried out prior to the middle of this century. An exception is the work of Florin (1940a, 1963) which had a major impact on understanding of Southern Hemisphere biogeography.

A literature search revealed many macrofossil records of plants which are now extinct in the land mass where they were found, but which have extant relatives in one or both of the other land masses under consideration (appendix). However, not all of these records are reliable, and some are so dubious that they are not even considered here. The Australian records all represent recent research which usually utilised modern methods of comparative morphology, and they are regarded as sound comparisons.

Three of the five taxa from New Zealand are regarded as sound records, Araucaria haastii, Casuarina avenacea, and Eucalyptus. Longfordia banksiaefolia has been compared by Holden (1982) with some extant species of Banksia, but the fossil specimens are only fragmentary impressions. Such material should be treated with the utmost caution in any discussion of extant affinities. Florin (1940a) noted the presence of Athrotaxis novae-zeelandiae in New Zealand, and was confident of the generic determination. However, recent research (Miller \& La Pasha 1983) has shown that other fossils thought to have close affinities to Athrotaxis are in fact distinct from it, and therefore a detailed reexamination of $A$. novae-zeelandiae is required.

Most of the South American fossils in the appendix are well established, but two require discussion. Frenguelli (1953) described Eucalyptus macrofossils from Argentina. One of the authors (RSH) has examined fossil leaves and fruits of this taxon, and considers it highly probable that they are reliable records of Eucalyptus. Athrotaxis ungeri should be regarded with caution for the reasons given for $A$. novae-zeelandiae. The affinity of $A$. ungeri is complicated because Townrow (1965b) described specimens of this species from Tasmania, where Athrotaxis occurs today. However, Townrow was unsure about the conspecificity of his material with A. ungeri, and doubts about the South American fossils do not necessarily apply to the Tasmanian specimens.

An examination of the appendix shows a predominance of gymnosperms (18 out of 28 species). This may reflect the antiquity of gymnosperms, and therefore the possibility that more of them were present during the Tertiary. However, vegetative gymnosperm fossils are usually easier to identify than angiosperms, and the bias towards gymnosperms may simply reflect this.

Many of the gymnosperms are found in association with particular angiosperm groups (e.g. Nothofagus) in both extant vegetation and in fossil deposits. This suggests that these gymnosperms probably dispersed across Gondwana with the angiosperms during the Cretaceous and Early Tertiary. There are several examples of this which will now be considered.

Araucaria hastiensis occurs with Nothofagus in the mid-late Eocene Hasties deposit from northeastern Tasmania. A. hastiensis is very similar to extant $A$. araucana, which is common at high altitudes in the Andes, often in association with Nothofagus species (mainly $N$. dombeyi, $N$. antarctica or $N$. pumilio) (Veblen \& Schlegel 1982). Hill (1990a) suggested that the Nothofagus/Araucaria association which currently exists in the Andes may have been present at low altitudes in Tasmania during the Tertiary. The high latitude of Tasmania in the Early Tertiary may have combined with topographical microsites to provide niches which were climatically suited (cool and shaded) for this association. If this was the case, the northward movement of Australia during the Tertiary would have greatly reduced this microsite effect with the steepening angle of the sun in the sky (Hill 1990a). The presence of another species similar to $A$. araucana from mainland Australia (A. balcombensis, appendix) may provide evidence for a similar association there.

The extant South American conifer Austrocedrus chilensis is principally associated with sclerophyllous, arborescent shrubs in the ecotone between forest and the Patagonian steppe on the eastern side of the Andes (Veblen \& Schlegel 1982), although it has also been recorded in association with other conifers and Nothofagus as a sub-canopy species (Veblen \& Lorenz 1987). While it occurs at elevations up to $1000 \mathrm{~m}$ it is primarily a low altitude shrub or small tree. Austrocedrus tasmanica, which is very similar to $A$. chilensis although it is only known from female cones, has been recovered from the Late Oligocene-Early Miocene Monpeelyata deposit (Hill \& Carpenter 1989). The vegetation represented in this sediment is interpreted as having a low, closed rainforest cover with more open vegetation 
near the lakeedge where the macrofossils were deposited (Macphai l etal. in press). The vegetation near the lake edge was probably a precursor of extant alpine and subalpine vegetation in Tasmania. The open nature of this vegetation is in keeping with the modern habitat of A. chilensis, and Nothofagus is a common component of the ma croflora, suggesting an association between it and A. tasmanica. However, evidence for this association is not as strong as that for the Nothofagus/ Araucaria association, and it is difficult to provide a reason for the extinction of Austrocedrus in Australia.

The Ol igocene Libocedrus species from northern Tasmania (appendix) are similar to species currently growing in New Zealand and New Caledonia. The three New Caledonian Libocedrus species occur in the Mt Humboldt region (de Laubenfels 1972) on the same soil type and in the same area as Nothofagus. At Little Rapid River, Pioneer and Cethana (all in Tasmania), where Libocedrus macrofossils occur, combinations including Acmopyle, Agathis, Araucaria, Decussocarpus, Prumnopitys, Nothofagus subgenus Brassospora (Hill \& Read 1990), small-leaved Myrtaceae, Proteaceae and Cunoniaceae occur, so the vegetation has some floristic similarity to that currently found in New Caledonia (Morat et al. 1986), although it should be stressed that there are also some distinct differences. L. plumosa occurs on the North Island of New Zealand up to $600 \mathrm{~m}$ altitude, and also in the northwest of the South Island, and L. bidwillii occurs mainly in montane and subalpine New Zealand forests, although it is present at low altitudes on the western coast of the South Island (Salmon 1980). Intermittent disturbance, including infrequent, large-scale catastrophic events such as earthquake-triggered landslides and/or more frequent, smaller scale, gap forming events, is the principal initiator of $L$. bidwillii regeneration (Veblen \& Stewart 1982, Norton 1983). It has been suggested that the disturbance regime may have been much higher in Tasmania at the time that Libocedrus occurred there (Hill 1987, Hill \& Carpenter 1989), and there is direct evidence of major vegetation disturbance during the Oligocene (Wells \& Hill 1989). Natural disturbance is now rare in southern Australia, and this may be part of the reason for the extinction of species which have disturbance-based regeneration strategies from that region. Decussocarpus brownei and Dacrydium tasmanicum (appendix) may fall into a similar category, but the ecology of their extant relatives is not well understood.

Dacrycarpus has a particularly interesting history in southern Australia during the Tertiary. Although only two species are listed (appendix) as having affinities outside the Australian region, there are many more fossil Dacrycarpus species known, especially in Tasmania (Greenwood 1987, Wells \& Hill 1989, and authors). Most of these fossil Dacrycarpus species either have their extant affinities in Malesia, or else their extant infrageneric affinities are unknown. Dacrycarpus was originally represented in southeastern Australia by species with relatively high proportions of both bilaterally and bifacially flattened leaves. However, during the Early Tertiary there was a general reduction in the amount of bilaterally flattened foliage among Dacrycarpus species and stomata were restricted to one leaf surface on the bifacially flattened foliage. By the end of the Tertiary, Dacrycarpus was extinct in southeastem Australia and today it is extinct throughout Australia. A restriction of stomata to one leaf surface during the period from Late Palaeocene to the early Oligocene is also found in the same region for Acmopyle. The authors hypothesise that this reduction in leaf area and restriction in stomatal distribution was a response to changing climate, and is a similar morphological response to that described by Hill (1983a, b, in press) for Nothofagus cunninghamii in Tasmania and possibly $N$. menziesii in New Zealand. Dacrycarpus and Acmopyle were also present in South America during the Tertiary (appendix), but are absent there today. It is not known whether there was a similar morphological response in South America to that described for these genera in Australia. However, it appears probable that they were widespread in high latitude parts of the Southern Hemisphere in the Early Tertiary (Cookson \& Pike 1953, Florin 1963, Greenwood 1987, Wells \& Hill 1989), but later in the Tertiary became extinct or migrated northwards into lower latitude forests which maintained a more suitable climate. Unfortunately the fossil Acmopyle from South America is only an impression, and its stomatal distribution can therefore not be determined. The single extant species of Dacrycarpus in New Zealand (D. dacrydioides) is the only living high latitude species. Its presence may reflect the maintenance of appropriate climatic niches in New Zealand during the Tertiary at times when they were no longer available in Australia or South America. Townrow (1965a) and Greenwood (1987) considered that $D$. praecupressinus from Australia may have affinities with $D$. dacrydioides, but we conclude that this is not so. However, the absence of Dacrycarpus from South America and Australia today suggests that the survival of $D$. dacrydioides in New Zealand is more a reflection of chance or possibly evolution in response to unique pressures in New Zealand. Ecophysiological research is required to clarify the niche occupied by D. dacrydioides.

The only angiosperms in Australia listed in the appendix are Nothofagus species. One of these has already been discussed in conjunction with Araucaria. The other, $N$. cethanica, has been recovered from the Early Oligocene Cethana deposit in Tasmania (Hill 
1984). Nothofagus cethanica is virtually indistinguishable from $N$. fusca, a New Zealand endemic. The Cethana deposit also contains remains of $N$. gunnii (Hill 1984), N. tosmanica (Hill 1983b), and several other undescribed Nothofagus species (R.J. Carpenter). Nothofagus gunnii remains in Tasmania today, and $N$. tasmanica belongs to the complex of species which evolved into the extant Tasmanian $N$. cunninghamii (Hill 1983a, b, in press). However, all other Nothofagus species at Cethana, including $N$. cethanica, represent lines which are extinct in Australia. The reasons for this are uncertain. They may involve the regeneration strategies of some Nothofagus species, since occasional catastrophic disturbance is an important factor in the regeneration of many extant Nothofagus species in somecircumstances (e.g. Veblen et al. 1980, 1981), and while catastrophic disturbance may have been a feature of the southern Australian landscape in the past that is no longer the case. Fire is an important feature of the Australian landscape today, and is certainly catastrophic, but it is not considered relevant here because it is largely associated with human occupation (Singh et al. 1981). However, the limited data on regeneration of $N$. gunnii suggests that infrequent disturbance may be a critical factor in allowing seedling establishment (Read \& Hill 1988), and yet this species has survived in Tasmania while others have not. Read et al. (1990) have considered how so many species in a single genus (Nothofagus) co-existed in relatively small geographic areas (single catchments) in the past from the point of view of the interaction between climate and species' physiological responses.

Only five species from New Zealand are recorded in the appendix and two of these are considered to be doubtful records (see earlier discussion). However, the other three species are of particular interest. Araucaria haastii has affinities with section Intermedia of Araucaria, which today is restricted to New Guinea. While it is interesting that this section is absent from New Caledonia, which has such a high proportion of the extant Araucaria species, its relevance is uncertain. A scanning electron microscope survey of the cuticular micromorphology of $A$. haastii to confirm the affinity with section Intermedia would be of great assistance.

Macrofossils of the Casuarinaceae are relatively common in New Zealand, despite their absence from the extant flora. Casuarina stellata (Campbell \& Holden 1984) has affinities with the extant genus Gymnostoma, which occurs today in New Caledonia and throughout Malesia, with one species in northeastern Australia (Johnson \& Wilson 1989). However, C. avenacea (Campbell \& Holden 1984) is more enigmatic. This species may be considered in conjunction with $C$. patagonica from South America (Frenguelli 1943, appendix), because superficially at least these two species are very similar. Frenguelli described $C$. patagonica as having apparently cylindrical branchlets and cones made up of seven parts with three or four visible on the fossil. Christophel (1980) re-interpreted the photographs of this species and suggested that it had four-sided twigs and cones with very few valves per whorl, with four a highly plausible number. He suggested that the cone valves are exserted and therefore that it was "equally if not more likely" that the fossil has affinities to the Gymnostomae (now the genus Gymnostoma). However, Christophel also noted that other genera in the Casuarinaceae may have from 3-20 leaves per sheath, and that exsertion of the cone valves "is essentially a subjective character". Certainly the cone valves of $C$. patagonica are nowhere near as exserted as the extant Gymnostoma species illustrated by Christophel (1980). Casuarina avenacea has been described from reproductive structures only, although Campbell \& Holden (1984) note that other specimens which may be conspecific bear branchlets with leaves in whorls of four. However, the cones of $C$. avenacea, at least in some cases, have five or six valves per whorl and clearly do not have affinities with Gymnostoma. The valves of $C$. avenacea are exserted and in all visible characters it is similar to $C$. patagonica. Therefore we believe that despite Christophel's (1980) interpretation, there is equal evidence in favour of $C$. patagonica not belonging to Gymnostoma. The evolutionary significance of $C$. patagonica and $C$. avenacea is uncertain. However, they do confirm the presence of a nonGymnostoma form of Casuarinaceae in New Zealand and possibly South America during the Tertiary.

The relevance of this similarity becomes clearer when another genus represented as fossils in New 'Zealand and possibly South America is considered Eucalyptus. While the fossils from New Zealand have not yet been formally described, there is little doubt that the leaves and fruits recovered belong to Eucalyptus (Pole 1989), although the closely related Angophora cannot yet be discounted. The South American fossils also consist of leaves and fruits (Frenguelli 1953). Pole (1989) recorded Eucalyptus and Casuarina avenacea together in Early Miocene floras from central Otago. This is highly reminiscent of modern associations in the Australian vegetation, and it is possible that similar associations occurred in South America. Thus a vegetation type which is regarded as uniquely Australian - Eucalyptus forest with sclerophyllous understorey species - was possibly widespread across Gondwana during part of the Tertiary. An important conclusion from this observation is that since neither Eucalyptus nor Casuarina are well equipped for long distance seed dispersal, they must have been extant on Gondwana prior to $55 \mathrm{Ma}$, when New Zealand separated from Australia/Antarctica. This adds a great deal of 
uncertainty to the early history of Eucalyptus, which has previously been regarded as having australian origin, althotgh Pryor \& Johnson (1981) noted that the presence in New Caledonia of Arillastrum, which shares a number of features with the Angophora suballiance of eucalypts, suggests an early origin for the genus.

A major problem associated with the apparent presence of Eucalyptus and non-Gymnostoma Casuarinacese in South America and New Zealand is their current absence from those land masses. In Australia Eucalyptus is dominant over much of the land surface, although this dominance is a relatively recent feature, probably associated with aboriginal firestick farming (e.g. Singh et al. 1981). However, the Tertiary record of Eucalyptus is little more abundant or convincing in Australia than in South America or New Zealand. Much more fossil evidence is required before there will be a satisfactory answer to this problem. Hill \& Gibson (1986) and Carpenter \& Horwitz (1988) have provided evidence that modern Eucalyptus leaves have little potential for fossilisation because of minimal water transport, and this is exacerbated by the fact that Eucalyptus often occurs on dry sites remote from potential sites of fossilisation. The fossil record of Eucalyptus is therefore likely to remain relatively obscure.

The remaining species in the appendix are South American fossils. Those which have not yet been discussed include two species of Akania, which now occurs only in the coastal rainforest area of southeastern Queensland and northeastern New South Wales (West 1983). The presence of these fossils in South America is further evidence for the close floristic relationship among Gondwanic forests, but not enough is known about the ecology or physiology of the extant species to allow cornment on its current, very restricted distribution. The presence of the other two species, Araucaria pichileufensis and Podocarpus boliviensis, in the fossil record of South America is less surprising than their absence in the living flora. Again, a lack of knowledge of the ecology and physiology of the living species makes it impossible to comment on the possible causes of their extinction in South America.

\section{CONCLUSION}

A review of the Tertiary macrofossil record for South America, Australia and New Zealand has revealed many examples of more extensive former distributions for plants with relatively localised distributions in the high latitude, Southern Hemisphere region today. Given the extremely fragmentary nature of the macrofossil record and the relatively small amount of research carried out to date, it can be assumed that this list represents only a fraction of the species which were more widespread in the past.

This review illustrates the danger of basing Southern Hemisphere biogeography solely on the distribution of living plants. It is notable that no such reconstructions have, for example, predicted a former Australian distribution for Austrocedrus, Libocedrus, Araucaria species related to A. araucana, or Nothofagus species closely related to $N$. fusca and $N$. dombeyi. Perhaps even more surprising, especially to Australian botanists, is the evidence for Eucalyptus and non-Gymnostoma forms of Casuarinaceae in New Zealand and possibly South America. These examples starkly illustrate the major advantage of the fossil record in biogeography. Fossil evidence is concrete and must be explained. Biogeographic hypotheses stand or fall on fossil evidence.

However, there is more to the results presented here than that. It is clear that particular species have been associated together in characteristic vegetation types for a very long time. The examples discussed here probably represent only a small proportion of these. Communities in dry areas or at higher altitudes are less likely to have left a fossil record, but may still have been present for a long time in a similar form to that found today. Therefore, there is strong evidence that the species in some communities migrate together, although there is no doubt that associations of species have changed dramatically during the Tertiary (Hill $1990 \mathrm{~b}$ ). Further research is needed to clarify the concept of community stability through time, and this should be one of the more important aims for future palaeobotanical work in the Southern Hemisphere. The fossil record still has a great deal of important information to yield, but it is clear from this review that there is enough information already to make it an essential source of data for all students of plant evolution and biogeography in the Southern Hemisphere.

\section{ACKNOWLEDGEMENTS}

This research is funded by the Australian Research Council and the Ian Potter Foundation. RJC is in receipt of a Commonwealth Postgraduate Research Award and benefitted from participation in the 1989 Trans-Tasman Ecological Forum.

\section{REFERENCES}

Barker, P.F. \& Burrell, J., 1977: The opening of Drake Passage. Mar. Geol. 25: 15-34.

BERRY, E.W., 1938: Tertiary flora from the Rio Pichileufú, Argentina. Geol. Soc. Am. Spec. Pap. 12: 1-149. 
BIGwood, A.J. \& Hill, R.S., 1985: Tertiary Araucarian macrofossils from Tasmania. Aust. J. Bot. 33: 645656.

Campbell, J.D. \& Holden, A.M., 1984: Miocene casuarinacean fossils from Southland and central Otago, New Zealand. N.Z. J. Bot. 22: 159-167.

Carpenter, R.J. \& Horwitz, P., 1988: Leaf litter in two Tasmanian creeks and its relevance to palaeobotany. Pap. Proc. R. Soc. Tasm. 122: 39-45.

Christophel, DC., 1980: Occurrence of Casuarina megafossils in the Tertiary of south-eastern Australia. Aust. J. Bot. 28: 249-259.

Coleman, P.J., 1980: Plate tectonics background to biogeographic development in the southwest Pacific over the last 100 million years. Palaeogeogr., Palaeoclimatol., Palaeoecol. 31: 105-121.

Cookson, I.C. \& PIKE, K.M., 1953: The Tertiary occurrence of Podocarpus (section Dacrycarpus) in Australia and Tasmania. Aust. J. Bot. 1: 71-82.

Crook, K.A.W., 1981: The break-up of the AustralianAntarctic segment of Gondwanaland. In Keast, A. (Ed.): ECOLOGICAL BIOGEOGRAPHY OF AUSTRALIA. W. Junk, The Hague: 2-14.

Crook, K.A.W. \& Belben, L., 1978: The southwest Pacific area during the last 90 million years. J. Geol. Soc. Aust. 25: 23-40.

DE LaubenFels, D.J., 1972: Gymnospermes. In Aubreville, A. \& Leroy, J.-F. (Eds): FLORE DE LA NOUVELLECALÉDONIE ET DÉPENDENCES. Muséum National d'Histoire Naturelle, Paris: 168 pp.

EtTingshausen, C. von, 1887: Bieträgezur kentniss der fossilen flora Neuseelands. Denkschr. Math.-natur. Kl. kaiser Akad. Wiss., Wien: 53 pp.

FLorIN, R., 1940a: The Tertiary fossil conifers of south Chile and their phytogeographical significance. Kungl. Svensk. Vetens.-Akad. Handl. 19.

FLORIN, R., 1940b: Die heutige und fruhere Verbreitung der Koniferengattung Acmopyle Pilger. Svensk. Bot. Tidskr. 34.

FLORIN, R., 1963: The distribution of conifer and taxad genera in time and space. Acta Hort. Berg. 20: 122-312.

Frenguelli, J, 1943: Restos de Casuarina en el Mioceno de el Mirador Patagonia central. Notas Museo Plata 8: 349-354.

Frenguellı, J., 1953: Restos del genero Eucalyptus en el Mioceno de Neuquen. Notas Museo Plata 16: 209 213.

Gandolfo, M.A., Dibbern, M.C. \& Romero, E.J., 1988: Akania patagonica n. sp. and additional material on Akania americana Romero \& Hickey (Akaniaceae) from Palaeocene sediments of Patagonia. Bull. Torr. Bot. Club 115: 83-88.

Greenwood, D.R., 1987: Early Tertiary Podocarpaceae: Megafossils from the Eocene Anglesea locality, Victoria, Australia. Aust. J. Bot. 35: 111-133.

HıL, R.S., 1983a: Nothofagus macrofossils from the Tertiary of Tasmania. Alcheringa 7: 169-183.

HILl, R.S., 1983b: Evolution of Nothofagus cunninghamii and its relationship to $N$. moorei as inferred from Tasmanian macrofossils. Aust. J. Bot. 31: 453-465.
Hill, R.S., 1984: Tertiary Nothofagus macrofossils from Cethana, Tasmania. Alcheringa 8: 81-86.

HıLl, R.S., 1987: Discovery of Nothofagus fruits corresponding to an important Tertiary pollen type. Nature 327: 56-58.

HıLl, R.S., 1990a: Araucaria (Araucariaceae) species from Australian Tertiary sediments - a micromorphological study. Aust. Syst. Bot. 3: in press.

HILL, R.S., 1990b: Evolution of the modern high latitude southern hemisphere flora: evidence from the Australian macrofossil record. Proc. 3rd I.O.P. Conf., Melbourne, 1988: in press.

Hill, R.S., in press: Tertiary Nothofagus (Fagaceae) macrofossils from Tasmania and Antarctica and their bearing on the evolution of the genus. Bot. J. Linn. Soc.

Hill, R.S. \& BIGwood, A.J., 1987: Tertiary gymnosperms from Tasmania: Araucariaceae. Alcheringa 1 1: 325-335.

HiLl, R.S. \& CARPENTER, R.J., 1989: Tertiary gymnosperms from Tasmania: Cupressaceae. Alcheringa 13:89102.

Hill, R.S. \& Gibson, N., 1986: Input of potential macrofossils into Lake Dobson, south central Tasmania. J. Ecol. 74: 373-384.

Hill, R.S. \& READ, J., 1990: A revised infrageneric classification of Nothofagus (Fagaceae). Bot.J.Linn. Soc., in press.

HoldeN, A.M., 1982: Fossil Lauraceae and Proteaceae from the Longford Formation, Murchison, New Zealand. J. R. Soc. N.Z, 12: 79-90.

HOOKER, J.D., 1860: FLORA TASMANIAE. VOL. I. DICOTYLEDONES. Lovell Reeve, London.

Johnson, L.A.S. \& Wilson, K.L., 1989: Casuarinaceae: a synopsis. In Crane, P.R. \& Blackmore, S. (Eds): EVOLUTION, SYSTEMATICS, AND THE FOSSIL HISTORY OF THE HAMAMELIDAE. Clarendon Press, Oxford: 167-188.

Kamp, P.J.J., 1986: Late Cretaceous-Cenozoic tectonic development of the southwest Pacific region. Tectonophysics 121: 225-251.

KEMP, E.M., 1978: Tertiary climatic evolution and vegetation history in the southeast Indian Ocean region. Palaeogeogr., Palaeoclimatol., Palaeoecol.24: 169208.

KEMP, E.M., 1981: Tertiary palaeogeography and the evolution of Australian climate. In Keast, A. (Ed.): ECOLOGICAL BIOGEOGRAPHY OF AUSTRALIA. W. Junk, The Hague: 33-49.

LAwver, L.A. \& SCOTESE, C.R., 1987: A revised reconstruction of Gondwanaland. In McKenzie, G.D. (Ed.): GONDWANA SIX: STRUCTURE, TECTONICS AND GEOPHYSICS. Geophysical Monograph 40. American Geophysical Union, Washington: 17-23.

Macphail, M.K., Hill, R.S., Forsyth, S.M. \& Well.s, P.M., in press. A late Oligocene-early Miocene cool climate flora in Tasmania. Alcheringa.

Martin, H.A., 1982: Changing Cenozoic barriers and the Australian paleobotanical record. Ann. Miss. Bot. Gard. 69: 625-667. 
Miller, C.N. \& LAPASHa, C.A., 1983: Structure and affinities of Atrotaxites berryi Bell, an Early Cretaceous conifer. Am. J. Bot. 70: 772-779.

Morat, P., Vellon, J.-M. \& MacKee, H.S., 1986: Floristic re lationships of New Caledonian rainforest phanerogams. Telopea 2: 631-679.

Norton, D.A 1983: Population dynamics of subalpine Libocedrus bidwillii forests in the Cropp River Vallep, Westland, New Zealand. NZ J. Bot. 21:127134.

Pole, M., 1989: Early Miocene floras from Central Otago, New Zealand. J. R. Soc. NZ 19: 121-125.

Pryor, L.D. \& Johnson, L.A.S., 1981: Eucalyptus, the universal Australian. In Keast, A. (Ed.): ECOLOGICAL BIOGEOGRAPHY OF AUSTRALIA. W. Junk, The Hague: 500-536.

READ, J. \& HLL, R.S., 1988: The dynamics of some rainforest associations in Tasmania. J. Ecol. 76: 558-584.

READ, J., HOPE, G.S. \& HILL, R.S., 1990: Integrating historical and ecophysiological studies in Nothofagus to examine the factors shaping the development of cool rainforest in southeastern Australia. Proc. $3 \mathrm{rd}$ I.O.P. Conference, Melbourne, 1988.

Romero, E.J. \& Hickey, L.J., 1976: A fossil leaf of Akaniaceae from Palaeocene beds in Argentina. Bull. Torr. Bot. Club 103: 126-131.

SALMON, J.T., 1980: THE NATIVE TREES OF NEW ZEALAND. Reed Methuen, Auckland: $384 \mathrm{pp.}$

Selling, O.H., 1950: Some Tertiary plants from Australia. Svensk. Bot. Tidskr. 44: 551-560.

Singh, G., Kershaw, A.P. \& Clark, R., 1981: Quaternary vegetation and fire history in Australia. In Gill, A.M., Groves, R.H. \& Noble, I.R. (Eds): FIRE AND THE AUSTRALIAN BIOTA. Australian Academy of Science, Canberra: 23-54.

SPICER, R.A., 1989: The formation and interpretation of plant fossil assemblages. Adv. Bot. Res. 16: 95-191.

STEIN, R. \& RoBerT, C., 1986: Siliciclastic sediments at sites 588, 590 and 591: Neogene and Paleogene evolution in the southwest Pacific and Australian climate. Initial Rep. Deep Sea Drill. Proj. XC: 1437-1455.
Stock, J. \& Molnar, P., 1987: Revised history of early Tertiary plate motion in the south-west Pacific. Nature 325: 495-499.

TownRow, J.A., 1965a: Notes on some Tasmanian pines I. Some Lower Tertiary podocarps. Pap. Proc. R. Soc. Tasm. 99: 87-108.

Townrow, J.A., 1965b: Notes on Tasmanian pines II. Athrotaxis from the Lower Tertiary. Pap. Proc. R. Soc. Tasm. 99: 109-113.

Truswell, E.M. \& Harris, W.K., 1982: The Cainozoic palaeobotanical record in arid Australia: fossil evidence for the origins of an arid-adapted flora. In Barker, W.R. \& Greenslade, P.J.M. (Eds): EVOLUTION OF THE FLORA AND FAUNA OF ARID AUSTRALIA. Peacock Publications, South Australia: $67-76$.

Veblen, T.T., Donoso, Z.C., Schlegel, F.M. \& Escobar, R.B., 1981: Forest dynamics in south-central Chile. J. Biogeogr. 8: 211-247.

Veblen, T.T. \& Lorenz, D.C., 1987: Post-fire stand development of Austrocedrus-Nothofagus forests in northem Patagonia. Vegetatio 71: 113-126.

Verlen, T.T. \& Schlegel, F.M., 1982: Reseña ecologica de los bosques del sur de Chile. Bosque 4: 73-115.

Veblen, T.T., Schlegel, F.M. \& Escobar, R.B., 1980: Structure and dynamics of old-growth Nothofagus forests in the Valdivian Andes. J. Ecol. 68: 1-31.

Veblen, T.T. \& Stewart, G.H., 1982: On the conifer regeneration gap in New Zealand: the dynamics of Libocedrus bidwillii stands on the South Island. $J$. Ecol. 70: 413-436.

Wells, P.M. \& Hill, R.S., 1989: Fossil imbricate-leaved Podocarpaceae from Tertiary sediments in Tasmania. Aust. Syst. Bot. 2: 387-423.

West, J.G., 1983: Akaniaceae. In Morley, B.D. \& Toelken, H.R. (Eds): FLOWERING PLANTS IN AUSTRALIA. Rigby, Adelaide: 204-205.

(accepted 2 February 1990)

R.S. Hill and R.J. Carpenter

Depar vent of Plant Science, University of Tasmania, GPO

Box 25 $\angle$ C, Hobart, Tasmania, Australia 7001 


\section{APPENDIX \\ Tertiary Macrofossil Taxa}

Described from a high latitude, Southern Hemisphere land mass (either southern Australia, New Zealand or southern South America) where they are currently extinct. In each case they are represented in the living flora of at least one of the other land masses at any southern latitude (shown in the second column). The publications in which the fossils are described are given in parentheses. (S.Am. $=$ South America, $\mathrm{NC}=$ New Caledonia, $\mathrm{NZ}=$ New Zealand, Aust. $=$ Australia, NG $=$ New Guinea.)

\section{Australian fossils}

Araucariaceae

Araucaria balcombensis

A. hastiensis

Cupressaceae

Austrocedrus tasmanica

Libocedrus jacksonii

L. mesibovii

L. morrisonii

Fagaceae

Nothofagus bulbosa

$N$. cethanica

N. lobata

Podocarpaceae

Acmopyle aberensis

A. florinii

A. glabra

A. setiger

Dacrycarpus involutus

D. mucronatus

Dacrydium tasmanicum

Decussocarpus brownei

\section{New Zealand fossils}

Araucariaeceae

Araucaria haastii

Casuarinaceae

Casuarina avenacea

Myrtaceae

Eucalyptus

Proteaceae

Longfordia banksiaefolia

Taxodiaceae

Athrotaxis novae zeelandiae

South American fossils

Akaniaceae

Akania americana

A. patagonica

Araucariaceae Araucaria pichileufensis

Casuarinaceae

Casuarina patagonica

Myrtaceae

Eucalyptus

Podocarpaceae Acmopyle engelhardti

Podocarpus boliviensis

Podocarpus (Dacrycarpus) inopinnatus

P. (Dacrycarpus) tertiarus

Taxodiaceae

Athrotaxis ungeri

\section{Living affinity}

Araucaria araucana (S.Am.) (Selling 1950, Hill 1990a)

A. araucana (S.Am.) ( Hill \& Bigwood 1987, Hill 1990a)

Austrocedrus chilensis (S.Am.) (Hill \& Carpenter 1989)

Libocedrus (NC, NZ) (Hill \& Carpenter 1989)

Libocedrus (NC) (Hill \& Carpenter 1989)

Libocedrus (NC, NZ) (Hill \& Carpenter 1989)

Nothofagus betuloides, N. dombeyi (S.Am.) ( Hill in press)

N. fusca (NZ) ( Hill 1984)

N. nitida (S.Am.) (Hill in press)

Acmopyle (NC, Fiji) (authors)

Acmopyle (NC, Fiji) (authors)

Acmopyle (NC, Fiji) (authors)

Acmopyle (NC, Fiji) (authors)

Dacrycarpus dacrydioides (NZ) (Wells \& Hill 1989)

D. vieillardii (NC) (Wells \& Hill 1989)

Dacrydium cupressinum (NZ) (Wells \& Hill 1989)

Decussocarpus rospigliosii (S.Am.), D. vitiensis (Morotai to Fiji)

(Selling 1950, Greenwood 1987)

Araucaria section Intermedia (NG) (Ettinghausen 1887, Florin 1940a, Bigwood \& Hill 1985, Hill \& Bigwood 1987)

Casuarinaceae, not Gymnostoma (Aust.) (Campbell \& Holden 1984)

Eucalyptus (Aust.) (Pole 1989)

Banksia (Aust.) (Holden 1982)

Athrotaxis cupressoides (Aust.) (Ettingshausen 1887, Florin 1940a)

Akania hilli (Aust.) (Romero \& Hickey 1976)

A. hilli (Aust.) (Gandolfo et al. 1988)

Araucaria section Eutacta (Aust., NG, NC) (Berry 1938, Florin 1940a)

Casuarinaceae (Aust.) (Frenguelli 1943), Gymnostoma (Aust., NG, NC) (Christophel 1980)

Eucalyptus (Aust.) (Frenguelli 1953)

Acmopyle pancheri (NC) (Berry 1938, Florin 1940b)

Podocarpus gnidioides (NC) (Berry 1938, Florin 1940a)

Dacrycarpus (NG, NZ) (Florin 1940a)

Dacrycarpus dacrydioides (NZ) (Berry 1938, Florin 1940a) 